\title{
The Annals and Lost Golden Statue of the Hittite King Hattusili I
}

\author{
Trevor R. BRYCE* \\ It is an honour to dedicate this article to Prof. Johannes Nolle, \\ in recognition of his many distinguished contributions to the \\ study of ancient Asia Minor
}

In the second half of the $17^{\text {th }}$ century $\mathrm{BC}$, Hatti, kingdom of the Hittites, began emerging as a major international power during the reign and as a result of the aggressive military operations of the Hittite king Hattusili I (c. 1650-1620). ${ }^{1}$ Our main source of information about these is a document which records the king's campaigns, supposedly over a period of five consecutive years and thus designated as the king's Annals. ${ }^{2}$

Following on from the campaigns of his predecessor (and grandfather?), the first Hittite king called Labarna, who had extended his sway over much of the eastern half of the Anatolian peninsula, Hattusili conducted campaigns in the northern parts of his kingdom, against the cities of Sanahuitta and Zalpa. Located to the northeast of the Hittite capital Hattusa, Sanahuitta had rebelled against Labarna, and its inhabitants had set up an independent regime in the city. ${ }^{3}$ Hattusili subsequently led his troops against the city, but failed to capture it on his first attempt and had to content himself with plundering and ravaging the countryside around it. He did, however, succeed in capturing and sacking the city of Zalpa, which probably lay on the Marassantiya river (mod. Kizll Irmak, Classical Halys) not far from its entrance into the Black Sea.

These ventures occupied the 'first year' of the king's Annals. The 'second year' saw the beginning of Hatti's rise to international status when Hattusili led his troops across the Taurus on what was supposedly the first of probably many expeditions into northern Syria. At this time, much of the region was subject to the kingdom of Yamhad, sometimes referred to by the name of its capital Aleppo (Hittite Halab/p). But no mention is made of Yamhad/Aleppo in Hattusili's campaign, and to judge from the Annals, the king seems to have confined himself to plundering and destroying the city of Alalah on the Orontes river, and several other cities west of the Euphrates and north of Carchemish. Almost certainly, all the conquered territories were allied or subject to Yamhad.

* Prof. Dr. Trevor R. Bryce, School of Historical and Philosophical Inquiry, University of Queensland, St Lucia, Q 4072, Australia (tbryce2@bigpond.com).

${ }^{1}$ My dating of the reigns of Hittite kings is very approximate and based on the so-called Middle Chronology; see Bryce 2005, 375-82.

${ }^{2}$ CTH 4. Transl. by G. Beckman in Chavalas 2006, 219-22. For an overall account of the reigns of Labarna and Hattusili, see Bryce 2005, 61-95.

${ }^{3}$ CTH 6 (the so-called Testament of Hattusili I) \$20. Transl. by Beckman in Hallo - Younger 2003, vol. II , 81, Goedegebuure in Chavalas 2006, 226. 
Then in his 'third year', Hattusili led an expedition into the Arzawan lands, a conglomerate of territories located in the western half of the peninsula. ${ }^{4}$ The Annals devote just one sentence to this campaign, simply recording that Hattusili 'went to the land of Arzawa and took away its cattle and sheep'. In his absence, Hurrian forces from the east invaded his homeland, and all the king's subject-territories rebelled against him, leaving only the capital loyal and intact. News of this must have prompted Hattusili's hasty return from the west, to restore his control over his kingdom and reconquer the rebel states. But no reference is made in the Annals to campaigns of reconquest, beyond the recapture of the city of Nenassa without resistance (it was probably located just below the southern bend of the Marassantiya), and Hattusili's subsequent conquest of two other rebel lands, Ulma and Sallahsuwa.

The 'fourth year' of the Annals records Hattusili's final capture and destruction after a five months' siege of Sanahuitta, which had retained its independence since the reign of his grandfather, and campaigns of conquest of a number of other lands and cities, which apparently remained unsubdued after Hattusili had crushed the general uprising recorded in the previous year.

With his control fully restored over his subject-lands in Anatolia, Hattusili was ready to embark on another campaign into Syria. This is recorded in the 'fifth' and 'final' year of his Annals, and contains the most detailed account of all his campaigns. A long list of conquests is recorded, as one city and land after another fell to the king's forces, and details are given of the extensive plunder taken from the conquered and sacked cities, for transport back to the homeland. In the course of his conquests, the king crossed the Euphrates river, a military feat which he claims was accomplished by only one man before him, the legendary Akkadian king Sargon who had, centuries earlier, crossed the river from the other direction.

Surprisingly, comprehensive and devastating though this 'Year 5' campaign allegedly was, not a single reference is made to the major power in the region at this time, the kingdom of Yamhad/Aleppo. Nor is there any reference to the kingdom in Hattusili's earlier Syrian campaign. Why is it so conspicuous by its absence from Hattusili's Syrian campaigns? Did it play no part at all in defending its allies and subjects in the region? In any case, why did Hattusili apparently make no direct attack on the kingdom, or at least on its capital Aleppo during his alleged Syrian rampage? A fresh consideration of the actual nature of the text containing the king's Annals may provide some answers to these questions.

It is generally agreed that after the withdrawal of the Assyrian colonies around the middle of the $18^{\text {th }}$ century, writing was reintroduced into Anatolia by scribes brought back to Hattusa by Hattusili in the aftermath of his Syrian operations. These scribes wrote in the Babylonian version of the Akkadian language, which they impressed on tablets using the cuneiform script. Perhaps initially under the tutoring of such foreign scribes, the Hittite language (called Nešite by those who wrote and spoke it) was gradually adopted as the language of bureaucratic communications and records within the Hittite world. Akkadian was still used, however, as the lingua franca of the period, for documents such as international correspondence and treaties with foreign kings. Opinion has varied among scholars about how rapidly writing in the Hittite language developed after the introduction of the cuneiform script into the Hittite administrative system. Theo van den Hout's proposal is, in my opinion, the most plausible: Akkadian remained the language of official communication in the kingdom for a century or more after Hattusili's campaigns, and that it was only in the $15^{\text {th }}$ century that the shift to

\footnotetext{
${ }^{4}$ See Bryce 2012, 74-5.
} 
regularly recording official documents in Hittite was made, as scribes became more adept at writing the language. ${ }^{5}$ This would mean that the first version of the Annals, assuming it was composed in Hattusili's own lifetime, was written solely in Akkadian, and that at some later time, perhaps no earlier than the mid or late $15^{\text {th }}$ century, a Hittite version of it was also prepared during one of the recopying processes, alongside the Akkadian copy. Henceforth, both versions of the document, or what remained of it, were preserved in a bilingual text down to the last decades of the empire.

Like most other Hittite documents, the Annals have survived only in a late $13^{\text {th }}$ century copy, the last in a line of copies made over several centuries. There are generally only minor variations between the Hittite and Akkadian versions of the text. Consistent with van den Hout's proposals, I have suggested that the document was first composed in Akkadian and later translated into Hittite - contra the suggestions that both versions were composed at the same time or that the Akkadian version was translated from an original Hittite one.

That brings us to the matter of the writing surface or surfaces used for recording the original inscription. During its account of 'Year 5' of the campaign, the Hittite version of the Annals states: 'I made this golden statue of myself and set it up near My Lady, the Sun Goddess of Arinna. And I plated the wall with silver from top to bottom. ${ }^{\prime 6}$ This most likely means that Hattusili commemorated his campaigns by having them recorded on or in the surrounds of a golden statue, which was erected in a holy place, perhaps a sanctuary of the Sun Goddess of Arinna, chief female deity of the Hittite land. The sanctuary may have been located in the Hittite capital or possibly in the goddess' nearby cultcentre at Arinna (Alaca Höyük?). Here it was to serve as an inspiration for the king's successors and any other subjects of the king allowed access to the hallowed precinct where it was housed.

We have a number of instances of statues and stelae, both actual and attested, inscribed with the deeds or autobiographies of ancient Near Eastern kings. Notable among these is the statue of Idrimi, the $15^{\text {th }}$ century king of Alalah, now in the British Museum. ${ }^{7}$ Across the front of it is inscribed a 104line autobiography of the king. So too we have the autobiography of the Neo-Babylonian queen Adad-guppi, mother of King Nabonidus ( $6^{\text {th }}$ century B.C.). This is inscribed on two stelae found in Harran. ${ }^{8}$ Recently, two more (almost) identical stelae were discovered near İskenderun in southeastern Turkey, the so-called ARSUZ inscriptions. ${ }^{9}$ Dating to the late $10^{\text {th }}$ century BC, the stelae bore Luwian hieroglyphic inscriptions commissioned by a Neo-Hittite king called Suppiluliuma, ruler of Walistin (Assyrian Patin) in northwestern Syria and proclaiming victory over the land Hiyawa, located in the region of Classical Cilicia. The stelae were abandoned, for one reason or another, en route to their final destination; they were probably intended to be set up on the eastern and western boundaries of the conquered land. To these surviving monuments we may add attestations of inscribed statues and stelae which Neo-Assyrian kings claimed to have erected in or before cities and lands they conquered. ${ }^{10}$

\footnotetext{
${ }^{5}$ See van den Hout 2009a, 2009b.

${ }^{6}$ CTH $4 \$ 17$. Beckman notes that the Akkadian version simply reads 'a golden statue'.

${ }^{7}$ For details and a translation, see Greenstein 1995, 2423-8.

8 Transl. by A. L. Oppenheim, in Pritchard 1969, 560-2.

${ }^{9}$ Dinçol et al. 2015.

${ }^{10}$ For examples, see Bryce 2016, 77.
} 
To return to the Hittite world. Many Hittite kings probably had their exploits recorded and preserved on monuments of one kind or another; some may have been on public display, others accessible only to a select few. Apart from Hattusili's monument, however, there is only one attestation of an inscribed statue of a Hittite king. On a clay tablet dating to the reign of the last Hittite king Suppiluliuma II, we are told that a statue was set up by the king's father Tudhaliya IV to commemorate his conquest of the land of Alasiya (Cyprus). ${ }^{11}$ In this instance, the inscription was not an annalistic record of the whole or part of Tudhaliya's reign, but apparently commemorated only this one event within it. Prowess on the field of battle was an important component of royal ideology, and no doubt like many of his predecessors Tudhaliya did commission for posterity a comprehensive record of his military achievements. But no such record has survived, even in fragmentary form.

With the main exceptions of (a) Suppiluliuma II's hieroglyphic inscription carved on the Nişantaş (Nişantepe) monument in Hattusa (so worn that only a few words of it are identifiable, and it may in any case refer only to a specific episode, or episodes, in Suppiluliuma's career), (b) the hieroglyphic inscription of the same king in Chamber 2 of the Südburg monument in Hattusa, which records military operations Suppiluliuma conducted in southern Anatolia, ${ }^{12}$ and (c) the Yalburt hieroglyphic inscription, which records a military campaign by Tudhaliya IV against the Lukka Lands in the southwest of the peninsula, ${ }^{13}$ the remnants we have of the military careers of Hatti's kings are preserved only on clay tablets. But these tablets are purely archival records, available for consultation by scribes and other officials as the need arose. Almost certainly, prime exemplars of all these documents were presented in a more distinguished format - and located in more distinguished settings than the shelves of palace or temple archives.

This brings us back to Hattusili's Annals, and the matter of the king's golden statue. Taken at face value, the Annals span just five years of the king's reign, as we have noted. But there is little doubt that Hattusili reigned a good deal longer, for perhaps as many as thirty years. If so, then the Annals cover only a small part of his reign. Alternatively, what we have may simply be all that survives of a much longer document. This possibility is suggested by the remnant of a Colophon surviving in the Hittite version of the text, which Beckman restores and reads thus: '[First] tablet, [incomplete(?)], of the manly deeds of Hattusili'. ${ }^{14}$

That raises the question of what degree of correspondence there was between the inscription supposedly carved on the statue and the one recorded on clay tablets - assuming that the first version of the Annals dates back to Hattusili's reign. If in their complete form, the Annals covered the whole of Hattusili's reign, it seems most unlikely that an inscription on the statue could have contained more than a summary of the chief events of the reign, or indeed covered more than a specific period or event within it. A text inscribed on a statue or stele could be quite extensive, as demonstrated by the Idrimi and Adad-guppi inscriptions. But a single statue or stele would almost certainly have been unable to accommodate a full account of a king's military career, especially if his reign was a long and active one, as Hattusili's very likely was.

\footnotetext{
${ }^{11}$ CTH 121. See Bryce 2005, 321-3, for discussion and references.

${ }^{12}$ Hawkins 1995, 21-65.

${ }^{13}$ Poetto 1993, Hawkins 1995, 66-85.

${ }^{14}$ Beckman 2006, 222.
} 
It is possible, of course, that the Annals in their official form were inscribed not on the statue itself, but on the walls of the sanctuary which housed the statue. These would presumably have allowed space not simply for what survives of the Annals, but for a detailed, comprehensive account of Hattusili's military career. Generally speaking, I think it not unlikely that most if not all Hittite kings had their achievements carved on statues or stelae which were set up in public venues or in other settings appropriate for their display. But in most if not all cases, these monumental inscriptions probably recorded no more than one or more episodes of special note of a king's reign, or a summary of the reign as a whole.

In that event, did the clay tablet records provide the only full account of a king's reign, or at least his military exploits?

I have suggested that the walls of a special place honouring the king, perhaps a sanctuary dedicated to his memory after his death, may have been used to provide a full record of his military achievements. Another (not mutually exclusive) possibility is suggested by the Colophon of the Seventh Tablet of the so-called 'Manly Deeds of Suppiluliuma'. This is the biography of Suppiluliuma I (c. 1350-1322) composed by his son and second successor Mursili II. ${ }^{15}$ The Colophon indicates that the text is 'incomplete and not yet made into a bronze tablet'. ${ }^{16}$ From this we can infer that a first draft of the Deeds was written on clay, which served as the basis for a final version to be inscribed on metal tablets.

What is attested for the Deeds of Suppiluliuma may well have applied to other royal biographies and sets of royal Annals, including those of Hattusili I. Full accounts of kings' reigns, or at least their military careers, may have been drafted firstly on clay tablets, then copied onto more durable metal tablets, especially bronze, which became their chief versions. These, I suggest, were kept in special locations, perhaps ancillary chambers of royal tombs, or sanctuaries dedicated to the kings's patron deities, and recited on special occasions - perhaps when cult ceremonies were performed in a deceased king's honour, or during coronation ceremonies of his successors. Copies of the prime exemplars were made on clay tablets, which were kept in the state archives whence they could be quickly retrieved whenever information from them was required.

In this context it is worth noting that the two chief versions of the 'Eternal Peace' treaty drawn up between the Hittite king Muwattalli II and the pharaoh Ramesses II (1259) were inscribed on silver tablets. ${ }^{17}$ And the bronze tablet unearthed in 1986 near the Sphinx Gate in Hattusa, a treaty between the Hittite king Tudhaliya IV and his cousin Kurunt(iy)a, subject-ruler of Tarhuntassa in southern Anatolia, provides a tangible example of the use of metal for such documents. ${ }^{18}$ If metal was used for important documents such as these, it is not unreasonable to suppose that the chief records of the

\footnotetext{
${ }^{15}$ Ed. and transl. by Güterbock 1956.

${ }^{16}$ Güterbock 1956, 97.

${ }^{17}$ Information provided by a fragmentary Akkadian version found in the tablet archives of Hattusa, and an Egyptian version inscribed on the walls of the temple of Amun (Karnak) and the Ramesseum (more fragmentary) in Egypt. For translations of both versions, see Pritchard 1969, 199-203 (Egyptian version by J. A. Wilson, Akkadian by A. Goetze). The Akkadian version has more recently been transl. by Beckman 1999, 96-100. For the most recent discussion of the two versions, see Jackson 2018.

${ }^{18}$ Otten 1988, also transl. by Beckman 1999, 114-24.
} 
careers of at least the most distinguished Hittite kings were also kept on metal tablets, as apparently Suppiluliuma's 'Deeds' were.

Hattusili's Annals is one of a number of bilingual documents, with both Hittite and Akkadian versions. Another, also dated to Hattusili's reign, is the king's so-called Testament, ${ }^{19}$ in which the ailing monarch rejects his nephew as his royal heir designate and appoints his grandson Mursili (I) to succeed him. Both the Annals and the Testament survive only in late $13^{\text {th }}$ century copies.

Let us consider now the matter of the Annals' reliability as a historical source of information for Hattusili's reign. There are a number of curious features of the surviving text that warrant comment. I shall refer to four in particular.

Firstly, as we have noted, the Annals for the 'second' and 'fifth' years record campaigns of conquest which Hattusili conducted in northern Syria - from Alalah, which served as a port city for the kingdom of Yamhad/Aleppo at the northern bend of the Orontes river, to cities in the Euphrates region, including Hahha (Hahhum) on the upper Euphrates. Yet in neither of these campaigns is any reference made to the kingdom of Yamhad/Aleppo itself, whose subject- and allied states Hattusili had attacked and destroyed. At face value, Yamhad offered no resistance to Hattusili during either campaign - and the second one is recorded in particular detail - nor did Hattusili apparently make any attack on Aleppo itself. References to Yamhad/Aleppo are conspicuous by their absence in the Annals. ${ }^{20}$ Yet there can be no doubt that the ultimate object of Hattusili's Syrian ventures was to destroy the kingdom, which he failed to do. Indeed, he may have been killed, or fatally wounded, in one final attack on Yamhad's capital, if we can so judge from a fragmentary text referring to his successor Mursili. This text records that 'Mursili set out against Aleppo to avenge his father's blood. Hattusili had assigned Aleppo to his son (to deal with). And to him the king of Aleppo made atonement..21 Mursili did in fact succeed, where his predecessor had failed, in capturing and destroying Aleppo, an accomplishment cast in the form of an act of revenge, quite possibly for the death of his 'father' (strictly his grandfather).

Secondly, in his 'second' Syrian campaign, Hattusili highlights his achievement in leading his troops across the Euphrates, thus emulating, and even outdoing, a similar achievement by the Akkadian Sargon, as we have noted. Yet we now know that Hattusili went beyond merely plundering and destroying cities in the Euphrates region. The relatively recently discovered letter (written in Akkadian) from Hattusili to Tunip-Teshub (Tuniya), ruler of the small kingdom of Tikunani in northern Mesopotamia, ${ }^{22}$ indicates that Hattusili regarded Tuniya as his subordinate. This implies that for a time he exercised some form of authority over part of northern Mesopotamia. If so, then the omission of this achievement from the Annals is surprising, since it surely overshadows the mere crossing of the Euphrates and the conquest of towns in the river region. On the other hand, it's possible that the Annals originally did contain a record of operations conducted by Hattusili beyond the Euphrates, and at least the temporary imposition of his authority over the region where he campaigned. But the existing tablet virtually ends with his conquests on the Euphrates, and a later part of the Annals which

\footnotetext{
${ }^{19}$ Transl. by Beckman in Hallo - Younger 2003, vol. 2, 79-81, Goedegebuure in Chavalas 2006, 222-8.

${ }^{20}$ Apart from a reference to a statue of the Storm God, Lord of Aleppo, among the spoils of conquest of the 'fifth' year.

${ }^{21}$ CTH 11A, 10-15.

${ }^{22}$ Published by Salvini 1984. Discussed by Bryce 2005, 78-80.
} 
might have recorded Hattusili's operations beyond the Euphrates has not survived - an implication that might be drawn from Beckman's reading and restoration of the Hittite version's Colophon.

My third comment concerns the record of events for Hattusili's 'third year'. We are informed that in this year (a) Hattusili went to Arzawa and brought back from it cattle and sheep; (b) the Hurrians invaded his homeland, and all his subject-lands rebelled leaving only Hattusa itself intact; (c) the king set out to attack the city of Nenassa (located just south of the Marassantiya river), presumably after driving the Hurrians from his land and restoring his authority over the other rebel states; (d) he then conducted campaigns against other hostile territories, Ulma and Sallahsuwa, before he returned to Hattusa, taking with him the spoils of conquest of these cities. All this allegedly happened within the space of a single campaigning season.

Let's consider the logistics of this. Generally, Hittite campaigns lasted from spring to early-mid autumn, though the campaigning season might sometimes be extended several more weeks, and very occasionally a Hittite expeditionary force might spend two consecutive years away from home, as Mursili II did on his first Arzawan campaign. ${ }^{23}$ But the severe winters on the Anatolian plateau which frequently resulted in Hattusa and other homeland areas being completely snowed in, were a major limiting factor on how long a Hittite army could spend each year on the campaign trail, especially if it took them far from home.

The year's account begins with an apparent livestock-rustling expedition by Hattusili to Arzawa. While the capture and transportation of cattle and sheep as part of the spoils of conquest were a regular feature of Hittite campaigns abroad, these were merely the aftermath of the campaigns themselves. We are not told how far Hattusili penetrated into Arzawan territory on this occasion, but given that the main Arzawa group lay in the far west of the Anatolian peninsula, a considerable part of a campaigning season must have been spent in getting to the region or regions which were the main objects of the campaign, and then getting back home at the earliest possible opportunity. Hittite texts provide extremely sparse information about the routes travelled by Hittite expeditionary forces, and almost no information about the rate of the army's march or the number of days taken to reach its destination. We can, however, extrapolate some useful information from campaign data recorded by Greek and Roman authors for later campaigns in the Anatolian region.

Of particular value is Xenophon's Anabasis, which provides a detailed account of Cyrus the Younger's expedition in $401 \mathrm{BC}$, in his abortive attempt to seize the Persian throne. Beginning in Sardis, in western Anatolia, Cyrus got as far as Cunaxa, a town on the Euphrates, before he was defeated and killed in battle by his brother Artaxerxes II. Xenophon, one of the Greek mercenaries hired by Cyrus, provides precise details of the expedition's route, including the distances travelled on each day's march. The first part of the route, from Sardis to Iconium (modern Konya), ${ }^{24}$ must have passed through much the same region traversed by many westward-bound Hittite armies. The journey between these cities, which involved a number of deviations from the most direct route, included

\footnotetext{
${ }^{23}$ Ten-Year Annals of Mursili for his third and fourth years, transl. by Beal 2003, 85-6.

${ }^{24}$ Xenophon, Anabasis 1,2,3-19.
} 
twenty-one marching days, ${ }^{25}$ averaging about twenty-one miles per day (converting Xenophon's Persian parasangs to miles on a 1:3+ ratio). Overall, this part of Cyrus' route covered about half the distance a Hittite army would have travelled to the west from its heartland.

On the assumption that an army's rate of march varied little over the centuries (though Alexander's troops sometimes covered more than forty miles per day), Hittite armies needed at least thirty-five marching days to travel from Hattusa to the furthermost parts of Arzawan territory, like Apasa (Classical Ephesos?) on the Aegean coast. Allowing for a number of deviations from the most direct route, for various logistical and strategic reasons, and adding in non-marching days for restocking supplies and for other factors affecting campaign progress, we can estimate an absolute minimum of seventy days for a Hittite army to reach a far western objective. At least double that number for the return journey, and add extra days for the battles themselves, the sacking of conquered cities, and the conveyance of livestock, deportees and other plunder back to the homeland. That amounts to virtually a whole campaign season for fully-fledged Hittite western campaigns. Of course, we do not know how far Hattusili penetrated Arzawan territory on the campaign recorded in his Annals. But even if this campaign did not take him to the furthermost limits of Arzawan territory, it must have involved a major military operation, of which the bringing back of cattle and sheep was merely the tail end, keeping the king long enough away from his homeland for a Hurrian invasion of it and widespread uprisings by rebellious subjects. Then on his return, the process of winning back his homeland from the Hurrian occupation forces (a process not mentioned at all in the Annals) and reconquering his rebel states must in itself have required a sustained military effort, and a substantial amount of time - after he had already spent many weeks, probably several months at least, on his Arzawan venture. It would have been impossible to achieve all this in a single campaigning season.

My fourth comment concerns the reference to the king's golden statue. As I've noted, this statue was very likely set up in an appropriate location in the capital, perhaps in a sanctuary of the Sun Goddess of Arinna, or in the nearby city of Arinna dedicated to the goddess. Alternatively, the statue may have been erected in a place set aside for the king's ancestor-cult after his death. Wherever its location, there may well have been an inscription carved on or near it commemorating Hattusili's military exploits. What is extremely odd is the insertion of a reference to the statue in the midst of an account of the king's second Syrian campaign. It is out of place here. One would have expected it to appear in a Colophon at the very end of the document in its complete form. And indeed, that's where it may originally have been located.

These four comments lead me to believe that part, probably most, of the original text of the Annals had already been lost in Hittite times, very likely destroyed, along with many other documents including the inscriptions carved on monuments (together with the monuments themselves), in one or more destruction episodes. While accidental outbreaks of fire must have been a constant hazard in Hattusa and other mudbrick-and-timber cities, enemy attack certainly cannot be ruled out, as a major cause of such episodes.

There are a number of possible contexts in which the destruction of a substantial part of Hattusili's Annals might have occurred. Let me suggest one possibility. From a later document, commonly referred to as the 'Concentric Invasions' text, we learn that Hattusa was destroyed in the late $15^{\text {th }}$ or

${ }^{25}$ The actual number of days spent on the journey was considerably greater, due to frequent and lengthy stops at various cities along the way. 
early $14^{\text {th }}$ century during incursions into the homeland and Hatti's peripheral territories, by enemy forces moving upon it from many directions. ${ }^{26}$ While some documents were no doubt retrieved from the city by the then king Tudhaliya III who evacuated the city before its destruction and set up a temporary headquarters and base of operations to the east of the invaded areas, others like Hattusili's Annals may have been largely destroyed, and the king's golden statue melted down or carried off when the city was torched.

However, a number of clay-copy fragments of the inscription survived by being baked in the fires which destroyed the tablet-archive rooms, even if the greater part of the inscription was lost. This is exactly the situation we have today with the retrieval of many accidentally baked tablets and tabletfragments unearthed in the Hittite capital. I suggest that Hittite scribes later tried to put together a sequence of events from the scraps of information found on the Annals' remaining fragments, in their efforts to recreate all they could of the document. What they did was to make a reasonably coherent compilation of the surviving pieces, compressing the episodes these pieces recorded into a period of five years. But in so doing, they lumped together events that may in fact have taken place years apart.

If this hypothesis is valid, then up to the time when the records of the Annals suffered significant destruction, and we have no clear idea of when this was, the composition was probably written in only one language - Akkadian. Subsequently, the remaining fragments of the document were pieced together in an attempt to provide a continuous account of Hattusili's achievements, though a much distorted and incomplete one. But by then, perhaps, Hittite had become the kingdom's official language, and when the reconstituted Akkadian text was made, a Hittite version was composed to go with it. This, I suggest, was the origin of the bilingual document which we have today.

My suggestion is, of course, highly speculative, and other scholars might well have quite different views about the document. One of the reviewers of this article has suggested that the 'composition was not concerned with describing Hattusili's military campaigns or their historical/political context, but rather with providing a detailed description of the booty acquired from said campaigns which were then dedicated mainly to the Sun Goddess of Arinna.' The reviewer further suggests that the composition was intended primarily as a dedicatory inscription to accompany the booty and the gold statue dedicated to the goddess, and that in this light, we may even suggest that the tablet was [complete].

This possibility cannot be ruled out. But the document's primary focus is clearly on the king's military activities and the victories he won, as demonstrated by the booty he brought back and often dedicated to one or other of the kingdom's deities. That is to say, the plunder listed in the aftermath of his campaigns is an appendage to them, not the main reason for recording them. The document clearly belongs within the context of the records of Hittite military campaigns and the listing of booty brought home from them. The reviewer's suggestion also leaves unexplained the various anomalies in the document, to which I have referred above, such as the impossibility of assigning all the events described in 'Year 3' of the document to a single campaigning season.

\footnotetext{
${ }^{26}$ The text, CTH 88, dates to the reign of Hattusili III (mid-13th century). For the most recent discussion of it (with translation) see Stavi 2015, 38-43, 60-5.
} 


\section{Bibliography}

Beal 2003

Beckman 1999

Beckman 2006

Bryce 2005

Bryce 2012

Bryce 2016

Chavalas 2006

CTH

Dinçol et al. 2015

Goedegebuure 2006

Greenstein 1995

Güterbock 1956

Hallo - Younger 2003

Hawkins 1995

Jackson 2018

Poetto 1993

Pritchard 1969

Otten 1988

Salvini 1984

R. H. Beal, The Ten Year Annals of Great King Muršili II of Hatti, in: W. W. Hallo - K. L. Younger (edd.), The Context of Scripture, vol. 2, 2003, 82-90.

G. Beckman, Hittite Diplomatic Texts, (2 $2^{\text {nd }}$ edn.) Atlanta 1999.

G. Beckman, The Annals of Hattusili I, in: M. W. Chavalas (ed.), The Ancient Near East, Oxford 2006, 219-222.

T. R. Bryce, The Kingdom of the Hittites, (new edn.) Oxford 2005.

T. R. Bryce, The Routledge Handbook of the Peoples and Places of Ancient Western Asia, London-New York 2012.

T. R. Bryce, The Land of Hiyawa (Que) Revisited, Anatolian Studies 66, 2016, 67-79.

M. W. Chavalas (ed.), The Ancient Near East, Oxford 2006.

E. Laroche, Catalogue des textes hittites (CTH), Paris 1971.

B. Dinçol et al., Two new inscribed Storm-God stelae from Arsuz (İskenderun) ARSUZ 1 and 2, Anatolian Studies 65, 2015, 59-77.

P. Goedegebuure, The Bilingual Testamentof Hattusili I, in: M. W. Chavalas (ed.), The Ancient Near East, Oxford 2006, 222-228.

E. L. Greenstein, Autobiographies in Ancient Western Asia, in: J. M. Sasson (ed.), Civilizations of the Ancient Near East, vol. 4, New York 1995, 2421-2432.

H. G. Güterbock, The Deeds of Suppiluliuma as told by his son, Mursili II, Journal of Cuneiform Studies 10, 1956, 41-68, 75-98, 101-130.

W. W. Hallo - K. L. Younger (eds.), The Context of Scripture (3 vols.), Leiden-Boston 2003.

J. D. Hawkins, The Hieroglyphic Inscriptions of the Sacred Pool Complex at Hattusa (SÜDBURG), Wiesbaden 1995.

S. Jackson, Contrasting representations and the Egypto-Hittite treaty, in: K. H. Keimer - G. Davis (edd.), Registers and Modes of Communication in the Ancient Near East, London-New York 2018, 43-58.

M. Poetto, L'iscrizione luvio-geoglifica di Yalburt. Nuove acquisizioni relative alla geografia dell'Anatolia sud-occidentale (Studia Mediterannea 8), Pavia 1993.

J. B. Pritchard, Ancient Near Eastern Texts Relating to the Old Testament, Princeton 1969.

H. Otten, Die Bronzetafel aus Boğazköy: ein Staatsvertrag Tuthalijas IV, Wiesbaden 1988.

M. Salvini, Une Lettera di Hattusili relativa alla spedizione contro Hahhum, Studi Micenei ed Egeo-Anatolici 34, Rome 1984, 61-80. 
Stavi 2015

van den Hout 2009a

van den Hout 2009b

B. Stavi, The Reign of Tudhaliya II and Šuppiluliuma I. The Contribution of the Hittite Documentation to a Reconstruction of the Amarna Age (Texte der Hethiter 31), Heidelberg 2015.

Th. van den Hout, A Century of Hittite Text Dating and the Origins of the Hittite Cuneiform Script, Incontri Linguistici 32, 2009, 11-35. Th. van den Hout, Reflections on the Origins and Development of the Hittite Tablet Collections in Hattuša and their Consequences for the Rise of Hittite Literacy, in: F. Pecchiolo Daddi - G. Torri - C. Corti (edd.), Central-North Anatolia in the Hittite Period. New Perspectives in Light of Recent Research. Acts of the International Conference Held at the University of Florence (7-9 February 2007) (Studia Asiana 5), Rome 2009, 71-96.

\section{Hitit Kralı I. Hattusili'nin Yıllıkları ve Kayıp Altın Heykeli}

Özet

Hitit başkenti Hattusa' daki kazılarda bulunan kil tabletler sözde eski Hitit kralı I. Hattusili' nin (yak. 1650-1620) askeri başarısının beş yılını kaydetmektedir. Genel olarak Hattusili'nin 'Yıllıkları' olarak bilinen bu belge (kralın) gümüş kaplamayla çevrili altın bir heykeline değinmektedir. Bu kaplamalar muhtemelen krala adanmış bir kutsal alanın bir kısmını oluşturmaktaydı. Burada, heykelin kendisinin, kaplamalarının veya her ikisinin de üzerinde olasılıkla yıllıkların ana versiyonu yazılmıştır. Günümüzde ikisi de kayıptır ve elimizde sadece kil tabletin yıllıklar hakkında anlatımı -ya da ondan arta kalanlar- vardır. Bu anlatımda yer alan büyük uyumsuzluklar ve bazı önemli eksikler bunu belgeleyen kil tabletlerin sadece kralın hükümdarlık döneminin çoğunu veya hepsini kapsayan çok daha büyük bir kompozisyonun fragmanları olduğunu belirtmektedir. Heykel ve içinde bulunduğu tapınağın (?) Hitit Dönemi’nde bir yangınla, kazara veya düşman tarafından tahrip edilmesinden sonra bu fragmanlar yıllıklardan kalan tek şeydir. Hititli kâtiplerin belgeyi yapabildikleri kadar yeniden yaratma çabaları ile sonradan yıllıklardan geride kalan fragmanlarda bulunan bölük pörçük bilgilerden olayların dizilişini birleştirmeye çalıştıkları bu makalede ileriye sürülmektedir. Onların yaptığı kalan parçaların makul şekilde uyumlu bir toparlamasını yaparak belgeledikleri bölümleri beş yıllık bir döneme sıkıştırmaktı. Ama bunu yaparak Hattusili’nin başarılarının aralıksız bir anlatımını -her ne kadar karmakarışık ve büyük eksikleri olan bir anlatım olsa da- sağlama girişiminde bulunarak aralarında yıllar olan olayları birleştirmişlerdi.

Anahtar Sözcükler: I. Hattusili; Yıllıklar (I. Hattusili); heykel (I. Hattusili); Hattusa; Arzawa; Yamhad/Halep; Akadca.

\section{The Annals and Lost Golden Statue of the Hittite King Hattusili I}

\section{Abstract}

Clay tablets excavated from the Hittite capital Hattusa supposedly record five years of the military exploits of the early Hittite king Hattusili I (c. 1650-1620). The document, commonly known as Hattusili's 'Annals', refers to a golden statue (of the king) housed in silver-plated surrounds. These surrounds probably formed part of a sanctuary dedicated to the king. Here what was probably the chief version of the Annals was recorded, on the statue itself, on its surrounds, or both. Both are now lost, 
and we are left with only the clay tablet account of the Annals - or what survives of it. Major inconsistencies in this account and a number of significant omissions from it, suggest that the clay tablets which record it were merely fragments of a much larger composition covering most or all the king's reign. These fragments were all that remained of the Annals when the statue and the sanctuary(?) which housed it were destroyed by fire in Hittite times, whether accidentally or by enemy action. I suggest that Hittite scribes later tried to put together a sequence of events from the scraps of information found on the Annals' remaining fragments, in their efforts to recreate all they could of the document. What they did was to make a reasonably coherent compilation of the surviving pieces, compressing the episodes they recorded into a period of five years. But in so doing, they put together events that may have taken place years apart, in an attempt to provide a continuous account of Hattusili's achievements, though a much distorted one with major omissions.

Keywords: Hattusili I; Annals (Hattusili I); statue (Hattusili I); Hattusa; Arzawa; Yamhad/Aleppo; Akkadian. 